\title{
Eukasz Jan Korporowicz. Prawo rzymskie w Anglii w XVIII wieku. Nauczanie, studia, nauka. Eódź: Wydawnictwo Uniwersytetu Eódzkiego, 2019, stron 237
}

\begin{abstract}
Eukasz Jan Korporowicz. Roman Law in Eighteenth-Century England. Teaching, Studying, Scholarship. Łódź: Lodz University Press, 2019, 237 Pages

This review presents a book recently authored by Łukasz Jan Korporowicz on the presence of Roman law in eighteenth century England. The book is divided into five chapters that deal with following issues: 1) teaching of ius civile in Oxbridge, 2) teaching of ius civile outside the universities, 3) the study of Roman law and obtaining formal degrees, 4) the impact of civil lawyers on the socio-political environment of England, and finally, 5) literature on Roman law.
\end{abstract}

Keywords: Roman law, English law, teaching law

Słowa kluczowe: prawo rzymskie, prawo angielskie, nauczanie prawa

Napisana świetnym językiem monografia jest kolejną pracą Łukasza Jana Korporowicza na temat obecności prawa rzymskiego w Anglii. Książka została podzielona na pięć rozdziałów korespondujących z podtytułem książki (nauczanie, studia, nauka): 1. Królewskie katedry i profesorowie prawa rzymskiego w Oxfordzie i Cambridge; 2. Prawo rzymskie jako przedmiot nauczania poza strukturą królewskich katedr; 3. Studiowanie prawa rzymskiego. Nadawanie stopni bakałarza i doktora prawa; 4. Cywiliści a życie społeczno-polityczne osiemnastowiecznej Anglii; 5. Literatura romanistyczna.

W pierwszym rozdziale autor interesująco zaprezentował stan nauczania prawa rzymskiego w uniwersytetach w Oksfordzie i w Cambridge (s. 17-46). Wiek XVIII stanowił okres zastoju tych słynnych ośrodków akademickich. Powszechne były wypadki nepotyzmu (s. 20), a niektórzy traktowali katedry uniwersyteckie jako synekury. Mimo trudności wykładów prawa jednak nie przerwano (s. 22), chociaż poziom nauczania nie był zadowalający. Zauważmy, że w omawianym okresie nie uczono już prawa kanonicznego 
(od czasów Henryka VIII). Skoro zaś dopiero w połowie stulecia powołano Vinerian Professorship of Common Law w celu nauczania prawa rodzimego, przez długi okres wykładano jedynie prawo rzymskie.

Królewskie katedry (Regius Professors of Civil Law) w Oxbridge nie były jedynym miejscem nauczania prawa rzymskiego (s. 47-77). Prowadzono także wykłady prywatne - zarówno w uniwersytetach (np. Thomas Wood, Thomas Beever; s. 47 i nast.), jak i w londyńskim Gresham College stanowiącym odpowiednik liceum (s. 72 i nast.). Prawo rzymskie było elementem edukacji młodych arystokratów mających prywatnych nauczycieli. W końcu zaś, co wydaje się niezwykle interesujące, wykłady na temat ius civile prowadzono w inns of court, a zatem w korporacjach prawniczych, które skupiały prawników praktykujących common law (s. 65 i nast., 207-8). Badania wskazują, że inns of court dokonywały nawet istotnych zakupów książek poświęconych prawu rzymskiemu (s. 71, 207-8).

W rozdziale trzecim autor wyjaśnia od strony praktycznej, jak wyglądało uzyskiwanie stopni akademickich na angielskich uczelniach (s. 79-120). To, czego brakuje w książce, to odpowiedź na pytanie, w jakim języku prowadzono wykłady - po angielsku czy wciąż po łacinie? Co dla nas dziś zaskakujące, studia prawnicze uważano wówczas za najtańszą i najprostszą metodę uzyskania wykształcenia uniwersyteckiego. Studia nie były przy tym jedyną ścieżką prowadzącą do zdobycia doktoratu - niektórym uniwersytety nadawały stopień w wykonaniu polecenia monarchy. Do grona takich oksfordzkich doktorów należał polski dyplomata - poseł Burzyński, uhonorowany tytułem w 1771 r. (s. 115).

Naukę prawa rzymskiego próbowano wiązać ze studiami nad prawem rodzimym. Zgodnie ze statutem elżbietańskim z 1571 r. obowiązującym w Cambridge, wymagano, by słuchacz po uzyskaniu doktoratu na tej uczelni podjął studia nad prawem rodzimym (s. 83). Z kolei oksfordzki Laudian Code z 1636 r. przewidywał, że na egzaminie doktorskim zadawane będą zarówno pytania z prawa rzymskiego, jak i angielskiego (s. 93). Badania wskazują, że w osiemnastowiecznej praktyce odstąpiono jednak od zadawania pytań z tej ostatniej kategorii (s. 94).

Jak wynika z lektury rozdziału czwartego (s. 121-156), cywiliści stanowili „poważne źródło intelektualnej elity Anglii” (s. 211). Absolwentem prawa na Cambridge był pierwszy angielski premier Robert Walpole (s. 149). Wielu innych zasiadało w Izbie Gmin (s. 151), pełniło urzędy w administracji kościelnej (s. 129 i nast.), stanowiącej w istocie część aparatu administracyjnego państwa, orzekało w sądach stosujących civil law (kościelnych, admiralicji itp.), a w końcu pełniło funkcje w dyplomacji (s. 149).

Autor wielokrotnie akcentuje tezę, wedle której angielscy absolwenci prawa nie stanowili - jak to dotąd powtarzano - wyizolowanej i zamkniętej grupy prawników. Wskazuje na wiele powiązań pomiędzy cywilistami wykształconymi w prawie rzymskim a barristers praktykującymi na co dzień przed sądami westminsterskimi stosującymi common law. Wielu owych barristers dysponowało stopniami akademickimi Oxbridge (s. 142 i nast., 208-9). Najczęściej mieli wyłącznie formalne wykształcenie, ale niektórzy z nich (nieliczni) praktykowali zarówno przed sądami stosującymi common law, jak i civil law (s. 144, 148). Do absolwentów Cambridge lub Oksfordu należeli wybitni prawnicy - baron Talbot pełniący funkcję lorda kanclerza (s. 147-148) oraz William Blackstone, a zatem pierwszy profesor prawa angielskiego i twórca Commentaries poświęconych właś- 
nie prawu rodzimemu (s. 146). Wszyscy osiemnastowieczni następcy Blackstone'a byli absolwentami Oxbridge: Robert Chambers, Richard Wooddeson, a w końcu i jego syn James Blackstone (s. 152).

Rozdział piąty (s. 157-205) to bardzo szczegółowy przegląd literatury romanistycznej. W tym miejscu autor ponownie zwraca uwagę na powiązania prawa rzymskiego i angielskiego. Pewien George Harris, komentując tłumaczenie Institutiones na język angielski, posługiwał się odwołaniami do orzeczeń pochodzących z law reports. Nawiązywał zatem do prawa angielskiego (s. 158-160). Jednym z ówczesnych komparatystów był Giles Jacob, który w pracy Treatise of Laws (London 1721) porównywał prawo angielskie i prawo rzymskie. Chociaż autor recenzowanej książki zżyma się na stosowaną przez Jacoba metodę omawiania poszczególnych instytucji prawnych według klucza alfabetycznego, należy wskazać, że układane w ten sposób leksykony, zwane $a b$ ridgments, były w Anglii popularne. Brak zdefiniowania porównywanych przez Jacoba angielskiej action i rzymskiej actio również nie powinien zaskakiwać. Niechęć do abstrakcyjnych definicji i preferowanie omawiania instytucji na konkretnych cases jest wszak typowe dla angielskiej kultury prawnej. (Dwadzieścia lat temu Peter Birks - red., English Private Law, vol. 1, Oxford 2000, s. XXXV - zarzucał swoim angielskim prawnikom „syndrom ludzi z metra” (stovepipe mentality) i wskazywał, że operują jedynie za pomocą konkretnych sytuacji faktycznych - cases, ale nie znają systematyki prawa. Tak samo jak owi „ludzie z metra” czerpią wiedzę o topografii Londynu ze znajomości poszczególnych stacji metra, ale nie znają w ogóle planu miasta.) Pod tym względem blisko angielskiej kulturze prawnej do stroniącego od pojęć ogólnych prawa rzymskiego (Omnis definitio in iure civili periculosa est). Warto zwrócić uwagę, że pewien autor, J. Pettingall, w dziele z 1769 r. poszukiwał początków angielskiej ławy przysięgłych w instytucjach starożytnych Grecji i Rzymu (s. 192).

$\mathrm{Na}$ aprobatę zasługuje wprowadzenie przez autora dwóch nowych polskich sformułowań - posługuje się on pojęciami Sąd Łuków (Court of the Arches; s. 134) oraz Kolegium Dusz Wszystkich Zmarłych (All Souls College; 148). Funkcjonują one w monografii wraz z obecnym od niedawna w polskiej nauce pojęciem Sądu Szachownicy. Autor stosuje je jednak zamiennie z terminem Sąd Exchequeru (s. 148), którego w moim przekonaniu należałoby unikać - piszmy konsekwentnie o Sądzie Szachownicy lub o Court of Exchequer. Podobnie wydaje się, że należałoby również stosować jednolitą pisownię miasta Oksford (najchętniej polską, a nie stosowaną w monografii angielską - Oxford). Jedynym poważnym mankamentem książki jest nieobecność indeksów (zwłaszcza indeksu osób). Wydaje się, że w przypadku monografii poświęconej studentom i ich profesorom (na kartach książki spotykamy ich naprawdę wielu) ten brak jest dostrzegalny.

Jak wskazano na wstępie, monografia została bardzo dobrze napisana i zasługuje na uważną lekturę czytelnika. Książka wypełnia lukę w dotychczasowych badaniach. Można jedynie liczyć na to, że niebawem ukaże się w angielskim tłumaczeniu i będzie dostępna również na Wyspach. 